Ryszard KOWALCZYK

Uniwersytet im. Adama Mickiewicza, Poznań

\title{
Miejsce i rola mediów lokalnych we współczesnym społeczeństwie informacyjnym (refleksje medioznawcze)
}

\section{Próba definicji pojęcia „media lokalne”}

7 anim przejdziemy do próby zdefiniowania pojęcia „media lokalne”, spróbujmy samą kategorię „media” przedstawić w trzech w zasadzie komplementarnych perspektywach, a mianowicie jako: 1) przekaz o określonych cechach (ujęcie przedmiotowe), 2) środek komunikowania i oddziaływania społecznego (ujęcie instytucjonalne) oraz 3) zespół ludzi zajmujących się działalnością wydawniczo-nadawczą i dziennikarstwem (ujęcie podmiotowe).

W konsekwencji pojęcie mediów lokalnych możemy potraktować jako kategorię formalną, która jest rezultatem podziału mediów według charakterystycznych kryteriów typologicznych. Dwa z tych kryteriów, a mianowicie zawartość (treść) oraz zasięg (terytorium rozpowszechniania) stanowią o istocie mediów lokalnych. Zawartość przesądza o ich uniwersalnym lub specjalistycznym bądź środowiskowym charakterze. Wyrazem uniwersalności treści jest wszechstronność zainteresowania (politematyczność). Specjalizacja i środowiskowość zaś są odpowiedzią na indywidualne bądź grupowe potrzeby określonych kategorii odbiorców (monotematyczność). Media lokalne dzielimy także według kryterium sposobu utrwalania informacji, który umożliwia ich podział na drukowane (prasa) i elektroniczne (radio, telewizja, internet).

Lokalny zasięg emisji zwykle ogranicza zakres zainteresowania mediów lokalnych. Mając ograniczony zakres zainteresowania oraz rozpowszechniania stanowią przeciwieństwo mediów ogólnokrajowych.

W praktyce polskiej pojęcie mediów lokalnych stosunkowo ściśle wiążą się z podziałem terytorialnym i administracyjnym kraju i wprowadzanym w ramach władztwa gminnego podziałem ich terytorium na mniejsze pomocnicze jednostki osadnicze (dzielnice, osiedla, sołectwa).

Dlatego posiłkując się kryterium zasięgu rozpowszechniania możemy współcześnie mówić między innymi o mediach lokalnych dzielni- 
cowych, osiedlowych, wiejskich, miejskich, gminnych, powiatowych, wojewódzkich.

Inny podział mediów lokalnych według zasięgu ich rozpowszechniania posiłkuje się kryterium zarówno demograficzno-geograficznym, jak kulturowym czy etnograficzno-kulturowym. Na tej podstawie media lokalne w Polsce lub raczej media nieogólnokrajowe możemy podzielić na: regionalne (jedno województwo), podregionalne lub subregionalne (kilka powiatów), mikroregionalne (powiat i miasto na prawach powiatu), lokalne (gmina lub miasto na prawach gminy), sublokalne (dzielnica, osiedle, sołectwo).

Oczywistym jest, iż powyższy podział mediów lokalnych pod względem zasięgu rozpowszechniania nie jest podziałem wyczerpującym wszystkie możliwości, bowiem nie obejmuje występujących w ramach miasta czy gminy mniejszych jednostek podziału, takich jak parafia czy obiekt zamknięty, na przykład: szkoła, uczelnia wyższa, szpital, dom pomocy społecznej, ośrodek opiekuńczy, warsztaty terapii zajęciowej, zakład karny, przedsiębiorstwo ${ }^{1}$.

Proponując przyjęcie powyższego podziału mediów lokalnych według takiego kryterium zasięgu ich rozpowszechniania, wychodzimy z założenia, iż w ramach na przykład województwa interesuje nas cały rynek mediów, czyli także te media, które mają zasięg wykraczający poza obszar jednego czy kilku sąsiednich powiatów (tradycyjnie media ukazujące się na tym obszarze traktowano jako media lokalne), lecz zwykle mieszczą się w granicach jednego województwa.

Na obronę tego stanowiska należy przywołać argument o stopniowalności pojęcia „lokalny”. W odniesieniu do mediów za najbardziej lokalne uznaje się takie, które obejmują najmniejszy z możliwych obszar rozpowszechniania. Natomiast najmniej lokalne są media, których obszar rozpowszechniania jest największy - oczywiście w ramach granic współczesnego województwa. Z oczywistych powodów podział ten rujnują możliwości internetu i jego wykorzystanie nie tylko do emisji różnorodnych, lecz tradycyjnych mediów, w tym mediów lokalnych, lecz także powstawanie w tym środowisku nowych, zwykle interaktywnych środków komunikowania społecznego (np. portali, wortali, blogów, komunikatorów, forów

${ }^{1}$ Szerzej na temat typologii mediów lokalnych w Polsce zobacz m.in. R. Kowalczyk, Media lokalne w Polsce, t. I, Poznań 2008, s. 169-189. O typologii prasy lokalnej zobacz m.in. M. Gierula, Polska prasa lokalna 1989-2000. Typologia i spoleczne funkcjonowanie, Katowice 2005; idem, Typologiczny rozwój prasy lokalnej w Polsce, „Studia Kieleckie. Seria Bibliologiczno-Prasoznawcza” 2003, nr 3. 
dyskusyjnych). W konsekwencji oznacza to globalny zasięg mediów lokalnych, których jednak zasadniczą cechą pozostaje terytorialnie ograniczone zainteresowanie.

\section{Media lokalne w społeczeństwie informacyjnym}

Media lokalne uczestnicząc w życiu społecznym, politycznym i ekonomicznym komunikują swoje istnienie, potrzeby, zainteresowania, funkcje, cele, opinie, poglądy. Natomiast biorąc udział w wymianie informacji określają relacje i wyznaczają związki, jakie je łączą z innymi podmiotami systemu lokalnego. W ten sposób partycypują w komunikowaniu lokalnym, stając się jego centralnym elementem. Jednak poprzez swoją działalność nie tylko oddziałują na pozostałe części lokalnego systemu społecznego, politycznego i ekonomicznego, ale również same w ramach sprzężeń zwrotnych podlegają ich wpływowi.

W rezultacie media lokalne nie tylko odzwierciedlają szeroko rozumiane życie społeczno-polityczne i ekonomiczne, ale także oddziałując na nie również je kształtują bądź nawet modelują czy kreują. Dlatego można je traktować dwojako - podmiotowo i przedmiotowo. $Z$ jednej strony występując jako ważny element życia społecznego, stają się podmiotem stosunków społeczno-politycznych i ekonomicznych oraz biorą czynny udział w ich odzwierciedlaniu i współkształtowaniu. Z drugiej zaś strony są ważnym forum dialogu, sporu, konfliktu, wymiany myśli, poglądów, opinii. Stanowią środek, za którego pośrednictwem jednostki i podmioty lokalne mogą się dzielić z innymi wrażeniami, ocenami, uwagami, pomysłami. W ten sposób wyraża się przedmiotowy charakter mediów lokalnych, które są użytecznym narzędziem i swoistym mechanizmem informowania i komunikowania oraz oddziaływania i wpływu społecznego.

Z punktu widzenia zadań i funkcji, media lokalne możemy postrzegać w trzech głównych i koherentnych perspektywach, a mianowicie środków zbierania i selekcji informacji, kształtowania i utrwalania informacji oraz dyfuzji informacji².

Szczególnej roli mediów lokalnych w życiu publicznym ${ }^{3}$ można upatrywać nie tyle w ich podmiotowym uczestnictwie w dialogu społecznym,

2 R. Kowalczyk, Media lokalne w Polsce, t. I, Poznań 2008, s. 98-128.

3 Media w życiu publicznym - wybrane zagadnienia, red. A. Balczyńska-Kosman, Poznań 2010. 
co nade wszystko w możliwości nadawania przez dziennikarzy odpowiednich znaczeń nagłaśnianym wydarzeniom, osobom, trendom, zjawiskom, instytucjom. W ten sposób media lokalne stają się nośnikiem nie tylko pewnych poglądów i opinii, lecz również wartości i norm, którym posługiwać się mogą nie tylko ich wydawcy-nadawcy i dziennikarze, ale także osoby z zewnątrz, zabierające w nich głos, również praktycy i teoretycy, w szczególności eksperci i naukowcy ${ }^{4}$. W rezultacie media lokalne są ważnym uczestnikiem i jednocześnie środkiem permanentnej dyskusji i dialogu publicznego, które toczyć się powinny w demokratycznym społeczeństwie obywatelskim ${ }^{5}$.

Dla niektórych badaczy zasadniczym odniesieniem dla komunikacji publicznej powinna się stać kategoria „dobra wspólnego”, którą zaakceptują ośrodki zarówno opiniotwórcze, w tym partie polityczne, organizacje pozarządowe, przedsiębiorcy i media lokalne, jak i decyzyjne, w tym przede wszystkim władze samorządu terytorialnego i państwowe. To zaś wymaga między innymi zmiany formuły komunikacji publicznej, czyli przejścia z informacyjnego, sprawozdawczego, diagnostycznego i beznamiętnego opisu rzeczywistości do empatycznego i wrażliwego uczestnictwa w jej przeobrażaniu ${ }^{6}$. Ważną rolę w tym procesie mogą odgrywać media lokalne.

Warto nadmienić, iż dla wielu badaczy i praktyków cechą właściwej komunikacji publicznej jest między innymi przestrzeganie reguł grzecznościowych. Dlatego zadaniem wypowiedzi publicznej nie jest tylko próba przedstawienia złożonej rzeczywistości oraz opinii i ocen jej dotyczących, lecz także zachowanie podczas jej referowania reguł i form grzecznościowych. Są one wyrazem podmiotowego traktowania zarówno uczestników programów radiowych i telewizyjnych oraz udzielających wypowiedzi

4 M. Lewiński, Treść i dyskurs jako przedmioty badań w analizie zawartości dyskursu, „2K - Kultura i Komunikacja” 2005, nr 1; M. Lisowska-Magdziarz, Analiza tekstu $w$ dyskursie medialnym, Kraków 2006; T. Zarycki, Dylematy budowy przestrzeni komunikacji i dialogu Polaków, w: Jak poprawić komunikację i dialog Polaków? $V$ Kongres Obywatelski, red. J. Szomburg, Gdańsk 2010, s. 5-14.

5 Szerzej na temat uczestnictwa obywateli, partii politycznych, władz publicznych, mediów w komunikacji i dialogu społecznym w Polsce zobacz m.in.: Jak poprawić komunikację i dialog Polaków? V Kongres Obywatelski, red. J. Szomburg, Gdańsk 2010.

${ }^{6}$ Zwraca na to uwagę m.in. R. Sojak, Jakość debaty publicznej w Polsce-najważniejsze bariery, w: Jak poprawić komunikację i dialog Polaków? V Kongres Obywatelski, red. J. Szomburg, Gdańsk 2010, s. 25-33. 
dla prasy, jak również odbiorców ${ }^{7}$. Nie ulega wątpliwości, iż także w mediach lokalnych występują przykłady wypowiedzi i zachowania, które świadczą o agresji, dominacji oraz niegrzecznym czy protekcjonalnym stosunku dziennikarzy do odbiorcy ${ }^{8}$. Nie nobilitują one dziennikarzy, a ponadto stanowią jeżeli nie istotę, to przynajmniej wyraz systemu ich wartości, wśród których język znajduje się na szarym końcu ${ }^{9}$.

Nie ulega wątpliwości, iż wśród mediów lokalnych są podmioty zarówno pozycjonujące się wobec władzy, jak i społeczeństwa. Sytuując się wobec władzy media lokalne raczej nie skupiają się na szeroko rozumianym odzwierciedlaniu potrzeb społecznych oraz o ile to możliwe również ich diagnozowaniu i agregowaniu, lecz koncentrują na kontroli działalności władzy, pełniąc ważną i zaszczytną funkcję tzw. czwartej władzy, co zapewne może im schlebiać. Jednak dla wielu badaczy niemniej ważną, czy bodaj nie najważniejszą funkcją mediów lokalnych jest próba opisu i klasyfikacji doświadczenia indywidualnego i zbiorowego oraz jego przedstawiania niejako pod osąd publiczny.

W rezultacie zasadniczym celem i misją mediów lokalnych powinno być poszukiwanie faktycznych możliwości rozwiązywania nabrzmiałych problemów społecznych przez odpowiednie instytucje społeczeństwa obywatelskiego i władze publiczne, a poprzez wnikliwą diagnozę także eliminowanie ich przyczyn. Dlatego niektórzy badacze zwracają uwagę na słabość kanałów komunikacji publicznej na poziomie lokalnym i niemożliwość właściwego wypełnienia roli zarówno kontrolnej, jak i diagnostycznej przez współczesne media lokalne: „Wiele wskazuje na to, że media lokalne nie są na przykład w stanie pełnić przypisywanej im kontrolnej roli w swoim bezpośrednim otoczeniu. Poziom uzależnienia od władzy w sytuacji mizerii finansowej [mediów lokalnych - RK], niesprzyjające systemowej pracy regulacje i formuły zatrudnienia dziennika-

${ }^{7}$ M. Marcjanik, Grzeczność w komunikacji językowej, Warszawa 2007; M. Marcjanik, Polska grzeczność językowa, Kielce 2002; Zmiany w publicznych zwyczajach językowych, red. J. Bralczyk, K. Mosiołek-Kłosińska, Warszawa 2001.

8 A. Awdiejew, Pragmatyczne podstawy interpretacji wypowiedzeń, Kraków 1987; Dialog a nowe media, red. M. Kita, J. Grzenia, Katowice 2004; Język w mediach masowych, red. J. Bralczyk, K. Mosiołek-Kłosińska, Warszawa 2000; M. Peisert, Formy i funkcje agresji werbalnej. Próba typologii, Wrocław 2004; J. Wasilewski, Retoryka dominacji, Warszawa 2006.

9 Język w kręgu wartości. Studia semantyczne, red. J. Bartmiński, Lublin 2003; U. Wieczorek, Wartościowanie. Perswazja. Język, Kraków 1999; T. Zgółka, Język wśród wartości, Warszawa 1988. 
rzy lokalnych oraz niska konkurencyjność [na rynku mediów lokalnych - RK] sprawiają, że lokalne gazety i radiostacje - jakkolwiek chętnie czytane i słuchane - bez wsparcia mediów ogólnopolskich niesłychanie rzadko są w stanie efektywnie wpływać na funkcjonowanie lokalnej władzy"10. Ten punkt widzenia, często artykułowany zarówno przez praktyków, jak i badaczy, godny jest uwagi, niemniej zarzut tamże podnoszony nie może dotyczyć wszystkich mediów lokalnych, lecz raczej nielicznych negatywnych przykładów, które znajdziemy w każdej grupie współczesnych mediów.

Zatem na działalność mediów lokalnych nie możemy spoglądać jednostronnie, z perspektywy tylko formalnej oraz zakładanych przez wydawców-nadawców a priori intencji, motywacji, założeń aksjologicznych, funkcji i celów. Powinniśmy ich działalność widzieć w szerszej perspektywie, biorąc także pod uwagę realizację ich bieżących interesów ekonomicznych i politycznych, jak i w dłuższej perspektywie, w której można identyfikować nie tylko symptomy pewnych zjawisk, lecz także odczytywać wyraźne tendencje obecne w zawartości mediów lokalnych oraz przeobrażenia zachodzące w ich sferze etyczno-aksjologicznej, warsztatowej i ekonomiczno-organizacyjnej. Właściwie dopiero szeroki paradygmat a posteriori (rozumiany w kategoriach faktycznych i mierzalnych efektów działalności zarówno po stronie nadawcy, jak i odbiorcy) czyni badania mediów lokalnych bardziej wartościowe i interesujące, bowiem umożliwiając identyfikację ich działań w złożonej siatce różnorodnych i czasowo nakładających się (jak i wykluczających) na siebie związków, uwarunkowań i determinant, umożliwia także ustalenie rodzaju i tempa przeobrażeń społecznych, politycznych, kulturowych, ekonomicznych, obyczajowych i innych, których media lokalne były nie tylko inspiratorem, lecz którym także podlegały. Dlatego bardziej wartościowy w tej perspektywie poznawczej jest paradygmat dualizmu (swoistej dwoistości skutków działania mediów lokalnych). Zakłada on, iż media lokalne wywołując i narzucając tematykę dyskursu publicznego, obnażając, krytykując i piętnując pewne zachowania, działania, postawy, wartości, nie tylko pełnią na przykład funkcję integracyjną, lecz także wywołując dysonanse, muszą również sprzyjać swoistej dezintegracji społecznej, czyli pełnić funkcję dezintegracyjną ${ }^{11}$. Zasięg i skala tych pro-

10 R. Sojak, Jakość debaty publicznej w Polsce-najważniejsze bariery, w: Jak poprawić komunikację $i$ dialog Polaków? V Kongres Obywatelski, op. cit., s. 29.

11 R. Kowalczyk, Integracyjna i dezintegracyjna rola prasy lokalnej, w: Zderzenie czy dialog państw narodowych w Europie, pod red. J. Sobczaka, A. W. Mikołajczaka przy udziale B. Hordeckiego, Poznań 2008, s. 327-348. 
cesów nie zawsze są i mogą być mierzalne, lecz zwykle są społecznie zauważane i identyfikowane, a także powszechnie odczuwane.

W rezultacie tak ujmowana swoista misja mediów lokalnych stanowi - z punktu widzenia paradygmatu republikańskiego społeczeństwa obywatelskiego i samorządnego oraz państwa prawnego, a także wskazań socjologii i psychologii komunikowania społecznego - jeden $\mathrm{z}$ ważnych elementów kreowania właściwych wzorów komunikowania się w nowoczesnym społeczeństwie obywatelskim i informacyjnym. Jednostki, grupy i organizacje uzyskują tym samym ważne narzędzie, jakim mogą się posługiwać w trakcie tworzenia i odtwarzania wzorów komunikowania społecznego zachodzącego w systemie lokalnym. Media lokalne są wówczas nie tylko źródłem wiadomości i wiedzy, zmniejszającym systematycznie lukę istniejącą pomiędzy rządzącymi i rządzonymi w dostępie do informacji, ale także wyrazem różnorodnych oczekiwań czy aspiracji społeczności lokalnych.

Rynek mediów lokalnych po 1989 roku systematycznie się powiększał, nasycając się rozmaitymi przejawami inicjatyw medialnych, w tym mediami wirtualnymi ${ }^{12}$. Coraz więcej czasopism lokalnych wydawały poszczególne wspólnoty parafialne, wykazując także zainteresowanie radiem lokalnym i serwisami internetowymi. Również samorządy osiedlowe, stanowiące organ pomocniczy gminy, a także samorządy gmin i powiatów zauważyły jak bardzo przydatnym instrumentem w procesie oddziaływania na opinię publiczną oraz wpływania na system lokalnego komunikowania społecznego są media lokalne. Są one nie tylko wygodnym środkiem komunikowania się z odbiorcami, ale spełniają także niemniej ważną funkcję - swoistego narzędzia artykulacji interesów różnorodnych podmiotów oraz forum przedstawiania potrzeb i oczekiwań społeczności lokalnych.

Współcześnie szczególnymi możliwościami kreowania, jak i odzwierciedlania opinii publicznej, wyrażającej różne poglądy na różne tematy i w różny sposób, dysponuje zarówno, telewizja ${ }^{13}$, jak internet, którego

12 Diagnoza Internetu 2009, pod red. K. Krejtz, Warszawa 2009; I. S. Fiut, Media @ Internet. Szkice filozoficzno-medioznawcze z lat 2000-2006, Kraków 2006; T. Skoczek, Regionalne i lokalne media elektroniczne. Systemowe możliwości rozwoju, Nowa Iwiczna 2007; idem, Telewizja regionalna - nowe rozwiqzania systemowe, Warszawa 2004.

${ }_{13}$ K. Badźmirowska-Masłowska, Wizerunek, czyli kiedy, kogo i jak można pokazywać w telewizji, Warszawa 2008; P. Bourdieu, O telewizji - panowanie dziennikar- 
rozwój niesie ze sobą w naturalny sposób elementy zarówno pozytywne, jak i negatywne ${ }^{14}$. W rezultacie internet stał się miejscem sprzyjającym nie tylko pozytywnemu rozwojowi człowieka, lecz także źródłem jego kulturowej degradacji ${ }^{15}$, o czym świadczy skala przykładów agresji i zachowań patologicznych czy nawet dewiacyjnych ${ }^{16}$, objawiających się $\mathrm{w}$ wirtualnym i nie zawsze przewidywalnym świecie.

Nadmierne korzystanie z internetu może prowadzić do samoizolacji społecznej, a nawet poczucia społecznego wyobcowania i swoistej ucieczki ze świata realnego, w którym występuje mnóstwo ograniczeń, do świata wirtualnego, bez materialnych, czasowych i przestrzennych przeszkód. Jednak zderzenie tych dwóch światów może skutkować nie tylko agresją, frustracją, depresją, przemocą ${ }^{17}$ czy próbami samobójczymi, ale również wręcz prowadzić do dewiacji ${ }^{18}$. Ich podłożem nie musi być jednak sam

stwa, Warszawa 2009; D. Dayan, Wydarzenia medialne - historia transmitowana na żywo, Warszawa 2008; K. Giereło-Klimaszewska, Rola telewizji w kształtowaniu wizerunku politycznego - studium mediatyzacji polityki na przykładzie wyborów prezydenckich $w$ Polsce, Torun 2008; M. Kowalski, M. Drożdż, Przemoc i zdrowie w obrazach telewizyjnych (edukacja przez ,, codzienność” telewizyjna), Kraków 2008; J. Kwiek, Telenowela a edukacja. Studium psychopedagogiczne, Poznań 2005; P. T. Nowakowski, Fast food dla mózgu, czyli telewizja i okolice, Tychy 2002; M. Jankowski, Kulturowe oddziatywanie telewizji $w$ epoce reality shows, Toruń 2004; N. Postman, Zabawić się na śmierć. Dyskurs publiczny w epoce show-businesu, Warszawa 2006; G. Ptaszek, Talk show. Szczerość na ekranie?, Warszawa 2007; G. Sartori, Homo videns - telewizja i postmyślenie, Warszawa 2007.

14 E-kultura, e-nauka, e-społeczeństwo, pod red. B. Płonki-Syroki, M. Staszczak, Wrocław 2008; Internet a psychologia - możliwości i zagrożenia, red. W. J. Paluchowski, Warszawa 2009; Nowe zjawiska w języku, tekście i komunikacji II, red. M. Rutkowski, K. Zawilska, Olsztyn 2008.

15 A. Keen, Kult amatora. Jak internet niszczy kulture, Warszawa 2007.

16 Poruszając problematykę społecznej patologii, mówimy także o zjawiskach społecznej dysfunkcji czy dezorganizacji, czyli również o psychopatologii, a więc poglądach, postawach i zachowaniach nieakceptowanych społecznie oraz niecieszących się szerszym uznaniem społecznym. Natomiast w zakres pojęcia dewiacji zwykle włącza się takie zachowania, jak: gwałt, kazirodztwo, kradzież, morderstwo. Por. R. Mayer, Psychopatologia, Gdańsk 2003; A. Nowak, E. Wysocka, Problemy i zagrożenia we współczesnym świecie. Elementy patologii społecznej i kryminologii, Katowice 2001; Patologie społeczne, red. M. Jędrzejko, Pułtusk 2006; I. Pospiszyl, Patologie społeczne. Resocjalizacja, Warszawa 2008; Zjawiska patologii spotecznej. Uwarunkowania, rozmiary, profilaktyka, prognozy, red. T. Sołtysiak, Bydgoszcz 1995.

17 Formy przemocy w kulturze współczesnej, red. H. Mamzer, Poznań 2006; Różne spojrzenia na przemoc, red. R. Szczepanik, J. Wawrzyniak, Łódź 2008.

18 L. A. Pervin, Psychologia osobowości, Gdańsk 2002. 
komunikat, dostarczany przez media, lecz sposób osobniczego, indywidualnego i nie zawsze przewidywalnego przetwarzania otrzymanej informacji ${ }^{19}$. W konsekwencji widzimy, jak media mogą się przyczyniać, świadomie bądź nieświadomie, do destrukcji współczesnych stosunków społecznych. W rezultacie wśród wielu niebezpieczeństw, których źródłem jest internet, możemy wyodrębnić m.in. zagrożenia zdrowotne, psychiczne, moralne oraz społeczne ${ }^{20}$.

Z perspektywy interesów zarówno mediów lokalnych, jak i społeczeństwa obywatelskiego niezmiernie ważkim zagadnieniem jest nie tylko problematyka rozwoju internetu, lecz kształtującego się w ślad za nim społeczeństwa informacyjnego. System ten może prowadzić do powstania specyficznej elity władzy, tzw. netokracji, której przewaga w komunikacji politycznej będzie wynikała między innymi z umiejętnego posługiwania się i wykorzystywania nowoczesnych mediów, w szczególności interne$\mathrm{tu}^{21}$, w procesie kreowania pozytywnego wizerunku ${ }^{22}$ (e-wizerunku $)^{23}$. Internet bowiem jest niezmiernie wdzięcznym narzędziem, którym posługujemy się w procesie nie tylko marketingu politycznego ${ }^{24}$, lecz również marketingu terytorialnego ${ }^{25}$. Stanowi to niemałe wyzwanie dla dziennikarzy mediów lokalnych, których jedno z zasadniczych zadań polega na kontroli władzy lokalnej ${ }^{26}$.

19 Internet a psychologia-możliwości i zagrożenia, red. W. J. Paluchowski, Warszawa 2009.

20 Media-komunikacja. Zdrowie i psychologia, red. B. Auoil, W. J. Maliszewski, Toruń 2007.

21 A. Bard, Netokracja. Nowa elita władzy i życie po kapitalizmie, thumaczenie P. Cypryański, Warszawa 2006; Demokracja a nowe środki komunikacji społecznej, red. J. Adamowski, Warszawa 2004; A. Rothert, Cybernetyczny porzadek polityczny, Warszawa 2005.

${ }^{22}$ T. Gackowski, M. Łączyński, Metody badania wizerunku w mediach, Warszawa 2009.

23 M. Łebkowski, E-wizerunek. Internet jako narzędzie kreowania i-mage'u, Gliwice 2010 .

24 S. Trzeciak, Marketing polityczny $w$ internecie, Warszawa 2010.

25 M. Florek, Podstawy marketingu terytorialnego, Poznań 2006; B. Gajdzik, Marketing w gminie - wybrane zagadnienia, Bytom 2002; W. Langer, Strategiczny marketing w rozwoju jednostki terytorialnej, Katowice 2006; Marketing terytorialny, red. T. Markowski, Warszawa 2002.

${ }^{26}$ Przyszłość dziennikarstwa $w$ dojrzatych demokracjach, red. P. J. Anderson, G. Ward, tłumaczenie Anna Piwnicka, Warszawa 2010; Społeczna przestrzeń interne$t u$, red. D. Batorski, M. Marody, A. Nowak, Warszawa 2006. 
Funkcjonowanie mediów lokalnych w istotnym stopniu jest obecnie określane przez zjawisko płynności, które obejmuje wachlarz przemian o charakterze ilościowym i jakościowym, kreujących proces komunikowania lokalnego. Jego ważnym elementem są media lokalne (czasopisma lokalne, radio lokalne, telewizja lokalna i inne środki utrwalania i przesyłania danych, w szczególności elektroniczna informacja lokalna w internecie). Proces ów jest stale tworzony i odtwarzany, a ponadto podlega silnemu oddziaływaniu nie tylko praw rynku i zmieniających się technologii oraz organizacji i funkcjonowania mediów, ale także oczekiwań i potrzeb heterogenicznych społeczności lokalnych. Czego wyrazem jest między innymi postępujący proces ich szeroko rozumianej specjalizacji, odpowiadającej także na potrzeby różnorodnych mniejszości, w tym mniejszości narodowych, etnicznych i religijnych ${ }^{27}$, grup niszowych czy społeczności alternatywnych $^{28}$, oraz niezmiernie szybko rozwijający się sektor lokalnych mediów wirtualnych ${ }^{29}$, a wraz z nimi pojawiający się specyficzny typ dziennikarstwa internetowego ${ }^{30}$ - preferujący między innymi swoisty lapidarny styl informowania ${ }^{31}$. Jego uzupełnieniem jest uprawiane w in-

27 Konflikt czy współdziałanie - media a problemy mniejszości, Kraków 1996; Media $w$ spoleczeństwie informacyjnym. Sekty i nowe ruchy religijne, pod red. I. Fajfer-Kruczek, Ł. Tomczyka, Cieszyn 2009; J. Mieczkowski, Prasa mniejszości narodowych i etnicznych w polityce państwa polskiego od 1989 roku, Szczecin 2007; Mniejszości narodowe i etniczne a media elektroniczne, pod red. A. Sadowskiego, T. Skoczka, Białystok 2001; B. Klimkiewicz, Mniejszości narodowe w sferze publicznej. Reprezentacje, praktyki i regulacje medialne, Kraków 2003; Regionalne i lokalne media w społeczeństwie wielokulturowym, pod red. J. Glenska, M. Kalczyńskiej, Opole 2004.

28 Antologia Zinów 1989-2001, opracowanie D. Ciosmak, Kielce 2001; Art-ziny. Zielonogórska twórczość alternatywna lat 90., Zielona Góra 2009; W. Kajtoch, Świat prasy alternatywnej w zwierciadle jej stownictwa, Kraków 1999; Xeroferia. Antologia, Warszawa-Zielona Góra 1993.

29 Z. Bauer, Dziennikarstwo wobec nowych mediów - historia, teoria, praktyka, Kraków 2009.

30 M. Mielcarek, Nowe media - nowe dziennikarstwo?, „Refleksje” 2010, nr 2, jesień-zima, s. 11-21; L. Olszański, Dziennikarstwo internetowe, Warszawa 2006. O dziennikarstwie internetowym zobacz także na: www.eredaktor.pl.

31 Tekst (w) sieci. Literatura, społeczeństwo, komunikacja, wyd. 12, red. A. Gumkowska, Warszawa 2009; Tekst (w) sieci. Tekst, język, gatunki, wyd. 11, red. D. Ulicka, Warszawa 2009; K. Wolny-Zmorzyński, W. Furman, Internetowe gatunki dziennikarskie, Warszawa 2010; J. Wrycza-Bekier, Webwriting. Profesjonalne tworzenie tekstów dla internetu, Gliwice 2010. 
ternecie tzw. dziennikarstwo obywatelskie, które przybiera coraz większe rozmiary $^{32}$.

W wyniku aktywnej działalności informacyjno-publicystycznej i reklamowo-ogłoszeniowej oraz rozrywkowej media lokalne stają się jednym z ważnych elementów kultury popularnej (w tym towarzyszącego jej swoistego języka komunikacji) ${ }^{33}$ i społeczeństwa masowego, który czynnie uczestniczy w procesie jego tzw. makdonaldyzacji ${ }^{34}$. Wyrazem tego procesu są między innymi szybkość reakcji mediów lokalnych na bieżące wydarzenia, zwiększająca się ilość szczegółowych informacji oferowanych odbiorcy oraz towarzysząca im wielość ujęć rzeczywistości, a także nadawanie specyficznego znaczenia wydarzeniom (np. opatrywanie ich nagłówkiem „Afera”, „Katastrofa”, „Korupcja”, „Szok” „Zboczenie”), zwykle nieadekwatnego do poziomu posiadanej w danym momencie wiedzy o tym wydarzeniu, i występująca w relacji dziennikarskiej podatność na jednoznaczność oceny, sądu, interpretacji - nie pozostawiająca wątpliwości odbiorcy, kto jest winien i dlaczego.

Rozwojowi mediów lokalnych towarzyszy kształtująca się wraz z nim swoista poetyka przekazu ${ }^{35}$. W ten sposób objawia się nam między innymi zjawisko pluralizmu mediów, który wyraża się nie tylko w obszarze ideowych, politycznych, kulturowych, religijnych i ekonomicznych inklinacji wydawcy i dziennikarzy, lecz również w specyficznym sposobie kształtowania przekazu medialnego i jego formie.

W konsekwencji olbrzymiego postępu w dziedzinie rozwoju mediów i usług wirtualnych, możemy mówić również o zjawisku konwergencji mediów ${ }^{36}$, w tym mediów lokalnych, które upodobniając się do siebie,

32 Do największych, ze względu na liczbę użytkowników, serwisów dziennikarstwa obywatelskiego w Polsce należą w kolejności: Wiadomosci24.pl, Interia360.pl, iThink.pl, eioba.pl, salon24.pl.

33 Studia nad komunikacja popularnq, międzykulturowa, sieciowa i edukacyjna, red. J. Fras, Toruń 2007.

34 G. Ritzer, Makdonaldyzacja społeczeństwa, Wydanie na nowy wiek, Warszawa 2005.

35 E. Szczęsna, Poetyka mediów - polisemiczność, digitalizacja, reklama, Warszawa 2007.

36 M. Drożdż, Konwergencja mediów. Tendencje, modele i konsekwencje, „Studia Medioznawcze" 2008, nr 3; H. Jenkins, Kultura konwergencji. Zderzenie starych i nowych mediów, Warszawa 2007. Konwergencję mediów ujmuje się w różnych perspektywach i konwencjach poznawczych, zwykle jednak traktuje się jako konwergencję: 1) zjawisk kultury, 2) systemów komunikowania masowego, 3) stosunków własnościowych w mediach, 4) techniczną (technologiczna), 5) transmisyjną, 6) rynkową, 7) produktów i usług medialnych. 
znajdują nie tylko wspólną platformę ich emisji, jaką jest współcześnie internet, lecz także środowisko powstawania nowych multimedialnych i interaktywnych wzorów i sposobów zarówno komunikowania się ludzi, jak i uprawiania różnorodnych przejawów twórczości ${ }^{37}$, właściwych naturze sieci cyfrowej i wirtualnej przestrzeni ${ }^{38}$. Rozwój lokalnych mediów elektronicznych przynosi ze sobą nie tylko szereg pozytywnych zjawisk i możliwości, lecz jest również źródłem nowych problemów społecznych, politycznych, prawnych, ekonomicznych, kulturowych, obyczajowych ${ }^{39}$.

Media lokalne podtrzymując system publicznej wymiany informacji i opinii mogą sprzyjać dialogowi demokratycznego społeczeństwa, w którym artykułowanie odmiennych potrzeb, oczekiwań i sądów powinno być zjawiskiem naturalnym, nie wywołującym nadmiernych niepokojów,

37 Estetyka wirtualności, red. M. Ostrowicki, Kraków 2005; Homo kreator czy homo ludens? Twórcy-internauci-podróżnicy, red. W. Muszyński, M. Sokołowski, Toruń 2008; M. Szpunar, Kultura obrazu a ikonosfera internetu, „Studia Medioznawcze" 2008, nr 3.

38 D. Batorski, M. Marody, A. Nowak, Społeczna przestrzeń internetu, Warszawa 2006; W. Gogołek, Komunikacja sieciowa. Uwarunkowania, kategorie i paradoksy, Warszawa 2010.

39 A. Adamski, Przestępczość w cyberprzestrzeni, Torun 2001; R. Aftab, Internet a dzieci. Uzależnienia i inne niebezpieczeństwa, Warszawa 2003; J. Barta, R. Markiewicz, Internet a prawo, Kraków 1998; W. J. Bober, Powinności w świecie cyfrowym. Etyka komputerowa w świetle współczesnej filozofii moralnej, Warszawa 2008; J. Bobryk, Świadomość człowieka w epoce mediów elektronicznych, Warszawa 2004; J. van Dijk, Społeczne aspekty nowych mediów. Analiza społeczeństwa sieci, Warszawa 2010; P. Fortuna, Psychologiczne mechanizmy obrony przed perswazyjnym wptywem telewizji, Lublin 2007; W. Godzic, Rozumieć telewizję, Kraków 2001; idem, Telewizja jako kultura, Kraków 2002; R. Golat, Internet - aspekty prawne, Warszawa 2003; S. Juszczyk, Człowiek w świecie elektronicznych mediów-szanse i zagrożenia. O problemach tworzacego się społeczeństwa informacyjnego, Katowice 2000; M. Kamińska, A. Horowski, Erotyzm, groza, okrucieństwo - dominaty współczesnej kultury, Poznań 2008; J. Mikułowski-Pomorski, Zmieniający się świat mediów, Kraków 2008; Problemy społeczeństwa informacyjnego, t 1 i 2, red. S. Szewczyk, Szczecin 2007; Przemoc i marginalizacja. Patologie społecznego dyskursu, red. P. Piotrowski, Warszawa 2004; M. Sokołowski, Oblicza Internetu. Internet w przestrzeni komunikacyjnej XXI wieku, Elblag 2006; Społeczno-kulturowe oddziatywanie mediów w dobie społeczeństwa sieciowego, praca zbiorowa, Mińsk Mazowiecki 2009; H. Tumolska, Dwa modele nadawcy prasowego po transformacji ustrojowej w Polsce - na przykładzie tygodników kaliskich, w: Między historia, politologia a medioznawstwem. Wybór problemów, pod red. T. Wallasa, Poznań 2010, s. 173-189; P. Werner, Łatwa ścieżka. Społeczeństwo a przestrzeń telekomunikacji i mediów elektronicznych, Poznań 2009;

J. Załubski, Media bez tajemnic, Poznań 2002. 
sporów czy konfliktów społecznych. Także Kościół Rzymskokatolicki, dostrzegając olbrzymie zalety mediów, w tym mediów lokalnych, w oddziaływaniu na odbiorców i kształtowaniu pozytywnych i zgodnych z nauką społeczną Kościoła wzorów osobowych, zwraca jednak uwagę na ich obowiązki wobec społeczeństwa oraz zagrożenia, jakie może nieść ze sobą ich dynamiczny rozwój ${ }^{40}$. Szczególne zagrożenia dla wiernych hierarchowie Kościoła widzą w bezkrytycznym korzystaniu z internetu ${ }^{41}$. Jak stwierdził papież Benedykt XVI: „Dzisiaj niemało młodych ludzi, oszołomionych nieskończonymi możliwościami, jakie dają sieci informatyczne czy inne technologie, nawiązuje formy komunikacji, które nie przyczy-

40 A. Baczyński, Telewizja w stużbie ewangelizacji, Kraków 1998; K. Czuba, Katolickie podstawy etyki dziennikarskiej, Torun 2007; G. Delmanowicz, Internet moralnym wyzwaniem dla człowieka Trzeciego Tysiqclecia w świetle wybranych dokumentów Kościoła, Przemyśl 2007; M. Drożdż, Logos i ethos mediów - dyskurs paradygmatyczny filozofii mediów, Kraków 2005; idem, Osoba i media. Personalistyczny paradygmat etyki mediów, Tarnów 2005; Dziennikarstwo wedhug Jana Pawła II, red. M. Miller, Warszawa 2008; J. P. Foley, Bóg w globalnej wiosce, Kraków 2002; K. Klauza, Media w nowoczesnej parafii. Sugestie pastoralne stare i nowe, Częstochowa 2003; Komunikacja wiary w trzecim tysiqcleciu, pod red. S. Dziekońskiego, Olecko 2000; Kościót a środki społecznego przekazu, praca zbiorowa, Warszawa 1990; Kościót i media w perspektywie komunikacyjno-pastoralnej, praca zbiorowa, Szczecin 2008; A. Lepa, Mity i obrazy, Łódź 1999; idem, Świat manipulacji, Częstochowa 1997; A. Lewek, Media i dziennikarstwo w nauczaniu Jana Pawła II, Warszawa 2008; K. Ligęza, ,Areopag” środków społecznego przekazu jako wyzwanie dla ewangelizacji wspótczesnej kultury w nauczaniu Jana Pawła II, Kraków 2000; J. Majewski, Religia, media, mitologia, Wydawnictwo Słowo/Obraz/Terytoria, Gdańsk 2010; Media w wychowaniu chrześcijańskim, praca zbiorowa, Lublin 2010; Media wyznaniowe w Polsce 1989-2004, pod red. E. Kossewska, J. Adamowski, Warszawa 2004; J. Miąso, Pedagogiczno-pastoralny model oddziaływania radia katolickiego w Polsce. Studium z zakresu pedagogiki medialnej, Rzeszów 2008; S. Mordarski, Media w działaniu. Funkcjonowanie środków społecznego przekazu w świetle nauczania Kościoła, Sandomierz-Kraków 2007; K. Pokorna-Ignatowicz, Kościót w świecie mediów - historia, dokumenty, dylematy, Kraków 2002; Prawda w mediach - między ideatem a iluzja, praca zbiorowa, Tarnów 2010; T. Reroń, Media na ustugach moralności chrześcijańskiej, Wrocław 2002; B. Secler, Kościót i media. Nastęstwa Dekretu Inter mirifica, w: Między historia, politologia a medioznawstwem. Wybór problemów, pod red. T. Wallasa, Poznań 2010, s. 209-219; P. Siuda, Religia a internet. O przenoszeniu religijnych granic do cyberprzestrzeni, Warszawa 2010.

${ }_{41}$ G. Delmanowicz, Internet moralnym wyzwaniem dla człowieka Trzeciego Tysiaclecia w świetle wybranych dokumentów Kościoła, Przemyśl 2007; P. Siuda, Religia a internet. O przenoszeniu religijnych granic do cyberprzestrzeni, Warszawa 2010. 
niają się do wzrostu w człowieczeństwie, lecz przeciwnie - grożą powiększeniem się poczucia samotności i odosobnienia"42. Także inne Kościoły zwracają uwagę na negatywne aspekty działalności mediów, podkreślając, że kształtują one w społeczeństwie niewłaściwą hierarchię wartości, w której pieniądz odgrywa decydującą rolę. „Sugerują one, iż ostatecznym celem jest życie ziemskie. Dla większości celem nie jest życie wieczne, lecz zdobywanie pieniędzy. [...] Mamona jest teraz głównym dobrem i taki obraz życia lansują nam środki masowego przekazu, oferując i głosząc nam niewłaściwą hierarchię wartości. Wypaczone ich pojmowanie wpływa również na samych wierzących" - stwierdził w orędziu noworocznym prawosławny arcybiskup białostocki i gdański Jakub ${ }^{43}$.

Wydaje się, że we współczesnych mediach lokalnych dominuje swoisty werbalizm, a wraz z nim instrumentalizm (pragmatyzm), emocjonalizm i idealizm, zwłaszcza widoczny w sferach politycznej i ideowo-religijnej oraz obyczajowej, a także szczególne zainteresowanie ogółem, grupą, wspólnota, sprawami publicznymi. Brakuje zaś w nich szerszego odniesienia do empirii, praktycyzmu, pragmatyzmu i racjonalizmu oraz jednostki, indywidualizmu, tolerancji i wolności ${ }^{44}$. W badaniach zwraca się również uwagę na problematykę uzależnienia odbiorców od mediów jako współczesnej postaci zniewolenia człowieka ${ }^{45}$.

Zwykle traktuje się media lokalne zarówno jako podstawę demokracji, jak i ważne narzędzie artykulacji interesów, opinii, wartości, a także walki o prawa i wolności ${ }^{46}$. Nie można zatem zapominać o ich w zasadzie fundamentalnej roli informacyjnej i opiniotwórczej, jaką odgrywają w naszym życiu zarówno indywidualnym, jak i zbiorowym, społecznym i publicznym.

42 http://www.wirtualnemedia.pl/artykul/benedykt-xvi-internet-powieksza-samotnosc-i-wyobcowanie (15.11.2010).

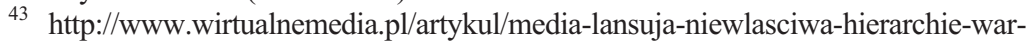
tosci (4.01.2011).

44 D. Dabert, Mowa kontrolowana. Szkice o języku publicznym w Polsce po 1989 roku, Poznań 2003; M. Lisowska-Magdziarz, Analiza tekstu w dyskursie medialnym, Kraków 2006; Polityka i perswazja, praca zbiorowa, Poznań 2007; Scena polityczna i media. Miraże sukcesu, ryzyko autoprezentacji, praca zbiorowa, Warszawa 2004; Tekst w mediach, pod red. K. Michalewskiego, Łódź 2002; W. Pisarek, O mediach i języku, Kraków 2007; E. Wilk, Nawigacje słowa. Strategie werbalne w przekazach audiowizualnych, Kraków 2000.

45 M. Czarniecki, W niewoli mediów, Opole 1999.

46 L. Staszyński, Środki przekazu - ostoja demokracji czy instrument walki?, Warszawa 1995. 
To na fundamencie sprawnie działających mediów lokalnych, przenoszących wiarygodne informacje od elit politycznych i władz publicznych do odbiorców i odwrotnie, może wyrastać nowa postać demokracji - demokracja uczestnicząca, partycypacyjna. Stanowi ona wyraz wysokiego zainteresowania społeczeństwa sprawami publicznymi, to zaś rodzi nadzieję, że taka postać demokracji będzie także sprzyjała szybszemu rozwojowi społecznemu, przynosząc również większe poparcie społeczne dla samej demokracji ${ }^{47}$.

Nie ulega także wątpliwości, iż media lokalne, będąc potencjalnie wpływowym narzędziem kształtowania opinii publicznej ${ }^{48}$, są wykorzystywane, często za ich przyzwoleniem, przez komórki public relations w procesie tworzenia pozytywnej opinii o działalności różnorodnych podmiotów ${ }^{49}$. W rezultacie działalności mediów lokalnych może powstawać sztuczne zjawisko wyciszania opinii publicznej lub odwrotnie - pobudzania opinii publicznej ${ }^{50}$. Zachowanie takie prowadzi do syndromu milczącej większości, która podlega wpływowi wszechpotężnych, chociaż różnorodnych mediów ${ }^{51}$.

Proces budowy rynku mediów o zasięgu lokalnym trwa nadal i miejmy nadzieję, że tak właśnie pozostanie i że będziemy mieli do czynienia ze stale ewoluującym systemem mediów lokalnych, dostosowującym się do wymagań ich odbiorców i zmieniających się uwarunkowań społeczno-politycznych i prawno-ekonomicznych ich funkcjonowania. Wydaje się, że zarówno dla życia publicznego (definiowanego w kategoriach złożonego układu relacji władza-obywatele, społeczeństwo-władza), jak również swoistego „zdrowia społecznego” (ujmowanego w kategoriach potrzeb indywidualnych i zbiorowych oraz możliwości ich artykułowania i zaspokajania), ta sytuacja jest pożyteczna ${ }^{52}$.

47 G. Satori, Teoria demokracji, Warszawa 1998, s. 137.

48 S. Kuśmierski, Opinia publiczna. Wprowadzenie do teorii, Wyższa Szkoła Ekonomiczna 1997.

49 S. Kuśmierski, Public relations w procesie opiniotwórczym, Almamer 2006.

50 E. Noelle-Neumann, Spirala milczenia. Opinia publiczna - nasza skóra społeczna, thumaczyła J. Gilewicz, Warszawa 2004.

51 J. Baudrillard, W cieniu milczqcej większości albo kres sfery społecznej, przełożył S. Królak, Sic! 2006.

52 W. Piątkowska-Stepaniak, Media na straży demokracji-utopia czy rzeczywistość, w: Media w wyborach. Kampanie wyborcze. Media w polityce, pod red. T. Sasińskiej-Klas, Toruń 2007. 
W przeciwnym wypadku, czyli swoistego zakończenia procesu kształtowania się rynku prasowo-wydawniczego i nadawczego na poziomie lokalnym i podziału stref wpływów pomiędzy poszczególne media i popierające je ugrupowania społeczno-polityczne, mielibyśmy zapewne do czynienia nie z heterogenicznym oraz policentrycznym układem relacji społecznych (właściwym dla systemu otwartego i demokracji deliberatywnej ${ }^{53}$ ), lecz ze spetryfikowanym oraz silnie spolaryzowanym systemem komunikowania lokalnego (właściwym dla systemu zamkniętego i autorytarnego), na który największy wpływ posiadałyby podmioty gospodarcze, polityczne, biurokratyczne i władze lokalne ${ }^{54}$. W tych warunkach niezorganizowane siły społeczne oraz organizacje pozarządowe i media lokalne byłyby swoistymi petentami, stojącymi u drzwi rządzących i posiadającymi niewielkie możliwości oddziaływania na kształt lokalnego systemu społeczno-politycznego, ekonomicznego oraz komunikowania lokalnego ${ }^{55}$. Zachowanie równowagi $\mathrm{w}$ tym obszarze praktyki społecznej jest podstawą sprawnie, chociaż nie bez okresowych perturbacji, funkcjonującej demokracji w społeczeństwie już nie tylko obywatelskim, lecz społeczeństwie także informacyjnym.

\section{Summary}

The author deals with the issue of the positioning of local media in a local information system. He considers this issue from the perspective of media studies and refers to the results of surveys carried out over the past twenty years, that is after 1989. The paper intends to present selected areas of the analysis of local media as an important participant in dialogue and a forum for the exchange of arguments in a local information system. The author emphasizes the social and political consequences of two fundamental paradigms of the functioning of local media, namely freedom of speech and accountability for one's words, which are considered not only in terms of the execution of the right to access information, but also in terms of the social responsibility of the media for the information they disseminate.

53 J. Węgrzecki, Przyszłość demokracji deliberatywnej, „Athenaeum. Polskie Studia Politologiczne" 2009, nr 22, s. 27-42.

${ }^{54}$ S. Michalczyk, Media lokalne, w: Polskie media lokalne na przełomie XX i XXI wieku, pod red. J. Jarowieckiego, A. Paszko, W. M. Kolasy, Kraków 2007; idem, Media lokalne w systemie komunikowania. Współczesne tendencje i uwarunkowania rozwojowe, Katowice 2000.

55 A. K. Piasecki, Samorzad terytorialny a media lokalne (1990-2002). Próba syntezy, „Zeszyty Prasoznawcze” 2003, nr 1-2. 